\title{
LXR Agonist T0901317-Induced Hyperlipidemia Does Not Lead to Lipid Accumulation in the Rat Heart
}

\author{
Dorota Harasiuk Marcin Baranowski Piotr Zabielski Adrian Chabowski Jan Górski \\ Department of Physiology, Medical University of Białystok, Białystok, Poland
}

\section{Key Words}

Liver X receptors $•$ Cardiac muscle $•$ Fatty acids $•$ Diacylglycerol $\bullet$ Cholesterol

\begin{abstract}
Background/Aims: Liver $X$ receptors ( $L X R \alpha$ and $L X R \beta)$ are ligand-activated transcription factors that regulate expression of genes involved in lipid and cholesterol metabolism. LXR expression has been identified in human and rodent cardiac tissue, however, its role in this tissue remains unclear. The aim of this study was to investigate effects of in vivo LXR activation on lipid metabolism in the rat myocardium under the conditions of low and high lipid intake. Methods: The experiments were performed on male Wistar rats fed for 5 weeks on either low fat diet (LFD) or high fat diet (HFD). Next, the animals were randomly divided into two groups receiving either LXR agonist - T0901317 $(10 \mathrm{mg} / \mathrm{kg} / \mathrm{d})$ or vehicle for the last week of the experiment. After anesthesia samples of the left ventricle and blood were taken. Results: It was found that LXR $\beta$ is the dominant isoform in the rat myocardium and the expression of both LXR isoforms did not change after administration of T0901317. Agonist treatment induced hyperlipidemia in low fat fed rats and this effect was amplified in high fat fed rats. LXR agonist elevated content of myocardial triacylglycerols in animals fed on LFD and content of phospholipids in animals fed on HFD. Levels of the remaining examined lipid classes (nonesterified fatty acids, diacylglycerol, free cholesterol, cholesterol esters, ceramide) was decreased or unchaged after LXR activation. Conclusion: We conclude that administration of T0901317 does not lead to severe myocardial lipid accumulation in rats despite of its high plasma availability.
\end{abstract}




\section{Introduction}

Liver X receptors (LXRs) are ligand-activated transcription factors that belong to the nuclear receptor superfamily [1]. There are two LXR isoforms termed LXR $\alpha$ and LXR $\beta$. LXR $\beta$ is expressed in all examined tissues, whereas LXR $\alpha$ expression is restricted to tissues with high level of lipid metabolism, such as liver, adipose tissue, intestine, macrophages and lungs [2]. Upon activation both isoforms form heterodimers with retinoid X receptor (RXR), and subsequently the LXR/RXR complex binds to the liver X receptor response element in the promoter region of the target genes and their transcription is stimulated [3]. Endogenous LXR ligands are oxysterols, oxygenated derivatives of cholesterol [4]. Synthetic LXR agonists T0901317 and GW3965, are commonly used in experimental studies and they activate both LXR isoforms with similar potency [3].

LXR expression has been identified in human and rodent cardiac tissue [2, 5-7]. LXR $\beta$ is the dominant isoform in the heart of mice $[2,5,8]$. Stimulation of LXRs with T0901317 in mice causes an increase in cardiac expression of genes involved in lipid and cholesterol metabolism, such as sterol response element binding protein 1c (SREBP-1c), stearoylCoA desaturase 1 (SCD1), ATP-binding cassette transporters A1 and G1 (ABCA1, ABCG1), known LXR target genes $[9,10]$. In addition the LXR agonist GW3965 increased intracellular triglyceride level in murine heart and isolated cardiomyocytes [8].

The most important role of LXRs is maintaining of cholesterol homeostasis. When the amount of cholesterol increases there is a subsequent accumulation of intracellular oxysterols [11]. It causes LXR activation which induces the transcription of genes involved in reverse cholesterol transport [3], its conversion to bile acids in the liver [12], excretion of cholesterol directly into bile [13] and decreasing intestinal cholesterol absorption [3, 11, 12, 14]. In addition, synthetic LXR agonists stimulate hepatic free fatty acid uptake and hepatic lipogenesis by induction of expression of fatty acid translocase/CD36 (FAT/CD36) [15] and SREBP-1c, respectively, which results in liver steatosis and hipertriglyceridemia $[16,17]$. Administration of LXR agonist, T0901317 or GW3965, normalizes also plasma glucose level and enhances insulin sensitivity in rodent models of type 2 diabetes and insulin resistance $[18,19]$.

Cardiac muscle is one of the most metabolically active tissues in the body and must continually generate ATP at a high rate for its contractile activity. Fatty acids are the main source of energy for the heart in the normal state [20]. The rate of fatty acid uptake depends on the concentration of fatty acids in the plasma [21]. Hyperlypidemia may cause lipid accumulation in the heart resulting from an imbalance between nonesterified fatty acids (NEFA) uptake and utilization [22].

LXRs as transcription factors regulate lipid metabolism in various tissues and cells. LXR expression has been noted in cardiac tissue, however its role in myocardial lipid homeostasis remains unclear. Lipids play many important roles in cardiomyocytes, for example they are energetic substrates, they determine fluidity and permeability of membranes, moreover they are precursors of signaling molecules and ligands for transcription factors. Therefore, the aim of this study was to investigate effects of in vivo LXR activation by the synthetic agonist T0901317 on lipid metabolism in the rat myocardium under the conditions of low and high lipid intake.

\section{Materials and Methods}

Animals

The investigation was approved by the Ethical Committee for Animal Experiments at the Medical University of Bialystok (permit no. 35/2008). Male Wistar rats (80-100g) were housed under controlled conditions $\left(21^{\circ} \mathrm{C} \pm 1,12 \mathrm{~h}\right.$ light $/ 12 \mathrm{~h}$ dark cycle, light on at 06:00 am) with unlimited access to water and laboratory rat chow. The animals were randomly assigned to either low-fat diet (LFD) or high-fat diet 
(HFD). Low fat diet (LSM, Agropol, Motycz, Poland) contained 16\% of metabolizable energy from fat, $62 \%$ from carbohydrates, and 22\% from proteins. High-fat diet (D12492 Research Diets, Inc.) contained $60 \%$ of metabolizable energy from fat, $20 \%$ from carbohydrates, and $20 \%$ from proteins. Next, the animals were randomly divided into two groups receiving either vehicle or a dual LXR $\alpha / \beta$ agonist T0901317 (Cayman Chemicals, $10 \mathrm{mg} / \mathrm{kg} / \mathrm{d}$ suspended in 0,5\% carboxymethylcellulose) for the last week of the experiment. The solutions were administrated once daily in the morning by an oral gavage. After five weeks of diet, the 24h after the T0901317/vehicle administration, all rats were anaesthetized by intraperitoneal injection of pentobarbital in the dose of $80 \mathrm{mg} / \mathrm{kg}$ (in the fed state). Blood taken from the abdominal aorta was collected in heparinized tubes, centrifuged, the plasma separated and flash-frozen in liquid nitrogen. Next samples of the left ventricle were excised and immediately freeze-clamped with aluminum tongs precooled in liquid nitrogen. All samples were stored at $-80^{\circ} \mathrm{C}$ until analysis.

\section{Myocardial lipids}

Ventricular samples were pulverized in an aluminum mortar precooled in liquid nitrogen. Lipids were extracted by the method of Folch. The fractions of total phospholipids, triacylglycerols, diacylglycerols, NEFA, free cholesterol and cholesterol esters were separated by thin-layer chromatography according to Roemen and van der Vusse [23]. Lipid were then transmethylated in either $1 \mathrm{M}$ methanolic sodium methoxide (Fluka) at room temperature for 10 minutes (triacylglycerols and phspholipids) or 14\% methanolic boron trifluoride (Sigma) at $100^{\circ} \mathrm{C}$ for either 2 (NEFA) or 10 (diacylglycerols) minutes. The content of resulting fatty acid methyl esters was determined using gas-liquid chromatography as previously described [24]. Free cholesterol and cholesterol esters were eluted from the gel with chloroform, evaporated under nitrogen stream and redissolved in 2-propanol or diethyl ether, respectively. The content of free cholesterol and cholesterol esters was subsequently measured with commercially available cholesterol diagnostic kit (BioMaxima). The content of ceramide was determined as previously described [25]. Briefly, tissue lipids were extracted into chloroform and the samples were then subjected to alkaline hydrolysis to deacylate ceramide. Free sphingosine liberated from ceramide was converted to o-phthalaldehyde derivative and analyzed using HPLC system. N-palmitoyl-D-erythrosphingosine (C17 base) was used as an internal standard.

\section{Real-time PCR}

Total RNA was isolated from 50mg of frozen tissue using Total RNA (A\&A Biotechnology) according to the producer's instructions. First strand cDNA was generated using High Capacity cDNA Reverse Transkription Kit (Applied Biosystem) according to the producer's instructions. PCR products were obtained by amplification of cDNA using primers as follows: forward: 5'- TGATGCTGAATTTGCTCTGC -3'; reverse: 5'- GGCTCACCAGCTTCATTAGC -3' for LXR $\alpha$; forward: 5'-TCTTTCTCCGACCAGCCTAA-3'; reverse: 5'-TCTCGTGGTTGTAGCGTCTG-3' for LXR $\beta$; forward: 5'-TCACACAATGCAATCCGTTT-3'; reverse: 5'-GGCCTTGACCTTGTTCATGT-3' for PPAR $\alpha$; forward: 5'-AACATCCCCAACTTCAGCAG-3'; reverse: 5'-TACTGCGCAAGAACTCATGG-3' for PPAR $\delta$; forward: 5'-CACACCCGCCACCAGTTC-3'; reverse 5'-GTAGGAGTCCTTCTGACCCATAC-3' for $\beta$-actin.

PCR was performed with SYBR Green JumpStart Taq ReadyMix (Sigma), using a Bio-Rad Chromo4 system. Reaction mix in final volume $25 \mu \mathrm{l}$ contained $12,5 \mu \mathrm{l}$ SYBR Green I, $3 \mu \mathrm{l}$ cDNA and 300nM of each primer pairs. PCR was carried out under following conditions: $15 \mathrm{sec}$ denaturation at $54^{\circ} \mathrm{C}, 1 \mathrm{~min}$ annealing at $55^{\circ} \mathrm{C}$ for PPAR $\alpha, 57^{\circ} \mathrm{C}$ for $\mathrm{LXR} \alpha, 58^{\circ} \mathrm{C}$ for $\mathrm{LXR} \beta, 63^{\circ} \mathrm{C}$ for $\beta$-actin, 1 min extension at $72^{\circ} \mathrm{C}$ for 40 cycles. PCR efficiency was examined by serial diluting the template cDNA, and a melt curve was performed after each reaction to verify PCR product specificity. A sample containing no cDNA was used as a negative control to verify the absence of primer dimmers. The results were normalized to $\beta$-actin expression measured in each sample. Relative expression of genes was calculated according to Pfaffl metod [26].

\section{Western blotting}

Myocardial samples were lysed in the RIPA buffer (pH 8,0 $50 \mathrm{mM}$ Tris-HCl, $150 \mathrm{mM} \mathrm{NaCl}, 1 \% \mathrm{NP}-$ 40, 0,5\% sodium deoxycholate1 mM EDTA, protease and phosphatase inhibitors). Protein concentrations were measured using Bicinchoninic Acid Solution (Sigma). Proteins were separated using 10\% SDSpolyacrylamide gel electrophoresis. Next, proteins were transferred to nitrocellulose membranes and the membrane was probed with primary antibodies against LXR $\alpha$, LXR $\beta$, FAT/CD36, $\beta$-actin (Abcam), SREBP-1 
Table 1. Effect of T0901317 treatment on body weight, food intake and plasma measurements in a fed state. The results are means \pm SD $(n=10)$. * - significant difference versus low fat diet (LFD) vehicle group. \# - significant difference versus high fat diet (HFD) vehicle group. NEFA - nonesterified fatty acids

\begin{tabular}{lcccc}
\hline & \multicolumn{2}{c}{ LFD } & \multicolumn{2}{c}{ HFD } \\
& Vehicle & T0901317 & Vehicle & T0901317 \\
\hline Initial body weight $(\mathrm{g})$ & $93.46 \pm 7.90$ & $94.40 \pm 7.49$ & $91.43 \pm 9.61$ & $94.27 \pm 8.98$ \\
Final body weight $(\mathrm{g})$ & $338.08 \pm 29.75$ & $344.10 \pm 27.66$ & $383.36 \pm 58.94 *$ & $365.53 \pm 33.41$ \\
Caloric intake $(\mathrm{kcal} / \mathrm{d} / \mathrm{rat})$ & $104.96 \pm 10.16$ & $107.28 \pm 13.81$ & $117.54 \pm 11.41$ & $100.23 \pm 14.87$ \\
Glucose $(\mathrm{mg} / \mathrm{dl})$ & $156 \pm 17$ & $133 \pm 11^{*}$ & $167 \pm 15$ & $147 \pm 22 \#$ \\
NEFA (nmol/ml) & $183 \pm 32$ & $246 \pm 44^{*}$ & $361 \pm 100^{*}$ & $631 \pm 220 \#$ \\
Triacylglycerols $(\mathrm{nmol} / \mathrm{ml})$ & $863 \pm 64$ & $1985 \pm 740^{*}$ & $1907 \pm 980$ & $6094 \pm 3113 \#$ \\
Total cholesterol $(\mathrm{nmol} / \mathrm{ml})$ & $1650 \pm 363$ & $1268 \pm 336$ & $2390 \pm 661 *$ & $2619 \pm 546$ \\
\hline
\end{tabular}

(Santa Cruz Biotechnology). After incubation with the secondary alkaline phosphatase-conjugated antibody (Sigma, A9019) protein bands were scanned and quantified using a Gel Doc EQ system (Bio-Rad). All samples were also probed with anti- $\beta$-actin antibody to verify equal loading. All samples were normalized to the $\beta$-actin expression.

\section{Plasma measurements}

Concentration of plasma glucose, triacylglycerols, NEFA and total cholesterol were determined with the use of Glucose Oxidase Reagent Set (Pointe Scientific Inc.), Serum Triacylglycerol Determination Kit (Sigma), wako NEFA C Kit (Wako Chemicals) and Cholesterol Kit (BioMaxima), respectively.

\section{Statistical analysis}

Data are presented as means \pm SD. Statistical analysis was performed using Statistica 9 (StatSoft). Statistical comparisons between experimental groups were made by using two-way ANOVA followed by Newman-Keuls post hoc test. P values $<0,05$ were considered statistically significant.

\section{Results}

Administration of T0901317 did not affect body weight or food consumption either in animals fed on LFD or in animals fed on HFD (Table 1). LXR activation resulted in a decrease in plasma glucose level in animals fed on either diet (Table 1). Plasma cholesterol, NEFA and triacylglycerols concentrations were increased after HFD feeding, however in the case of triacylglycerols the difference was not statistically significant (Table 1). LXR activation resulted in a further increase in plasma level of NEFA and triacylglycerols and the same changes were observed in the case of animals fed on LFD (Table 1). T0901317 did not affect plasma cholesterol level in animals fed on either LFD or HFD diet (Table 1).

There were no significant changes in the myocardial content of diacylglycerols and free cholesterol regardless of a diet and administration of T0901317 (Fig. 1). Administration of LXR agonist to rats fed on LFD decreased the content of myocardial ceramide and cholesterol esters, whereas the content of triacylglycerols was elevated (Fig. 1). High-fat diet caused accumulation of free fatty acids, triacylglycerols and phospholipids but reduced the level of ceramide in the heart. Activation of LXR receptors in rats fed on HFD elevated myocardial content of phospholipids, but decreased the content of myocardial NEFA and ceramide and did not affect the level of the remaining examined lipid classes (Fig. 1).

Both isoform of LXR were expressed in the rat heart as revealed by real-time PCR (Fig. 2) and LXR $\beta$ was more abundant isoform than LXR $\alpha$ (estimated difference after correction for PCR reaction efficiency was 2,7-fold, data not shown). T0901317 administration did not change myocardial mRNA expression of LXR isoforms either in animals fed on low fat diet or in animals fed on high fat diet (Fig. 2). LXR agonist did not induce changes in expression of 


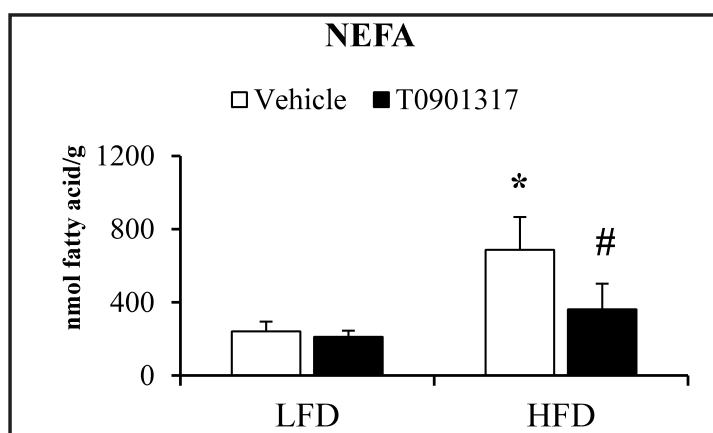

Triacylglycerol

$\square$ Vehicle $\boldsymbol{\square} \mathrm{T} 0901317$

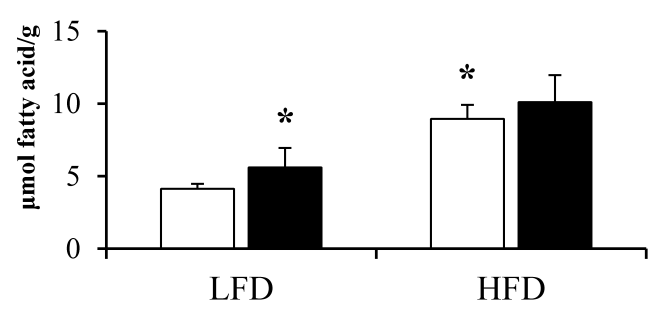

Free cholesterol

$\square$ Vehicle $\mathbf{\square} 0901317$

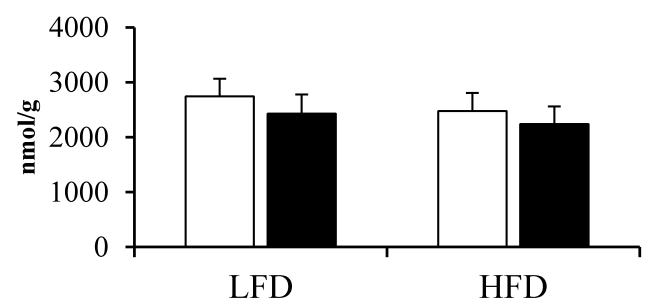

\section{Ceramide}

$\square$ Vehicle $\mathbf{\square} \mathrm{T} 0901317$

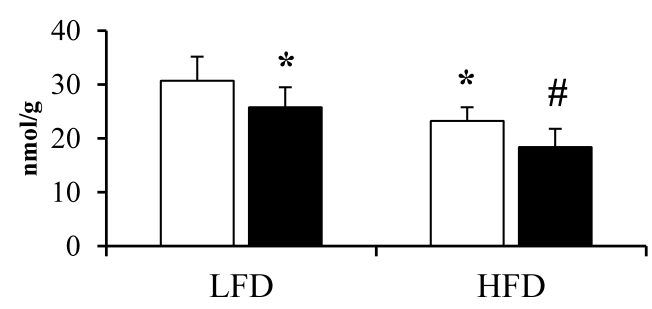

Diacylglycerol

$\square$ Vehicle $\mathbf{\square T} 0901317$

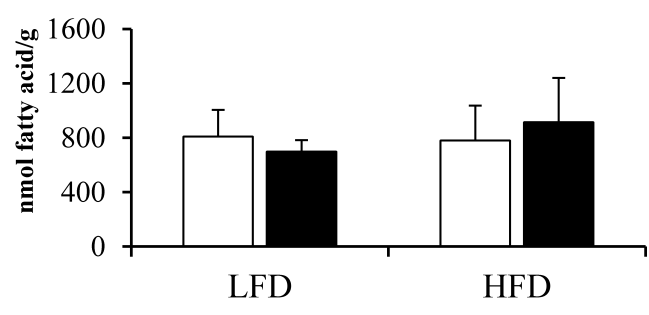

Phospholipids

$\square$ Vehicle $\boldsymbol{\square} \mathrm{T} 0901317$

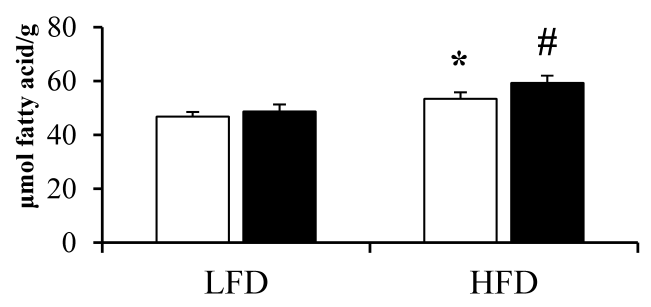

Cholesterol esters

$\square$ Vehicle $\boldsymbol{\square}$ T0901317

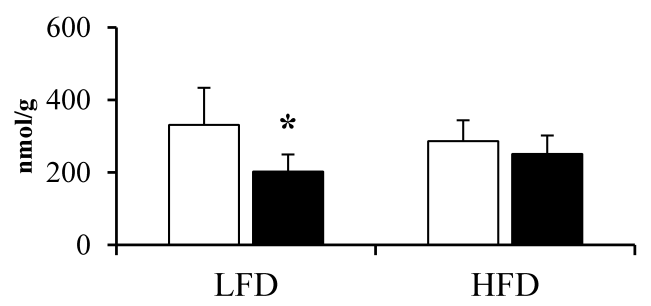

Fig. 1. Effect of T0901317 treatment on myocardial content of examined lipids. The results are means \pm SD $(\mathrm{n}=10)$ * - significant difference versus low fat diet (LFD) vehicle group. \# - significant difference versus high fat diet (HFD) vehicle group. NEFA - nonesterified fatty acids.

PPAR $\alpha$ and PPAR $\delta$ genes in animals on low fat diet (Fig. 2). High fat diet increased the level of PPARs mRNA in the rat heart (Fig. 2). T0901317 administration in high fat diet group decreased mRNA expression of PPAR $\alpha$ and PPAR $\delta$ compared to group with high fat diet alone 


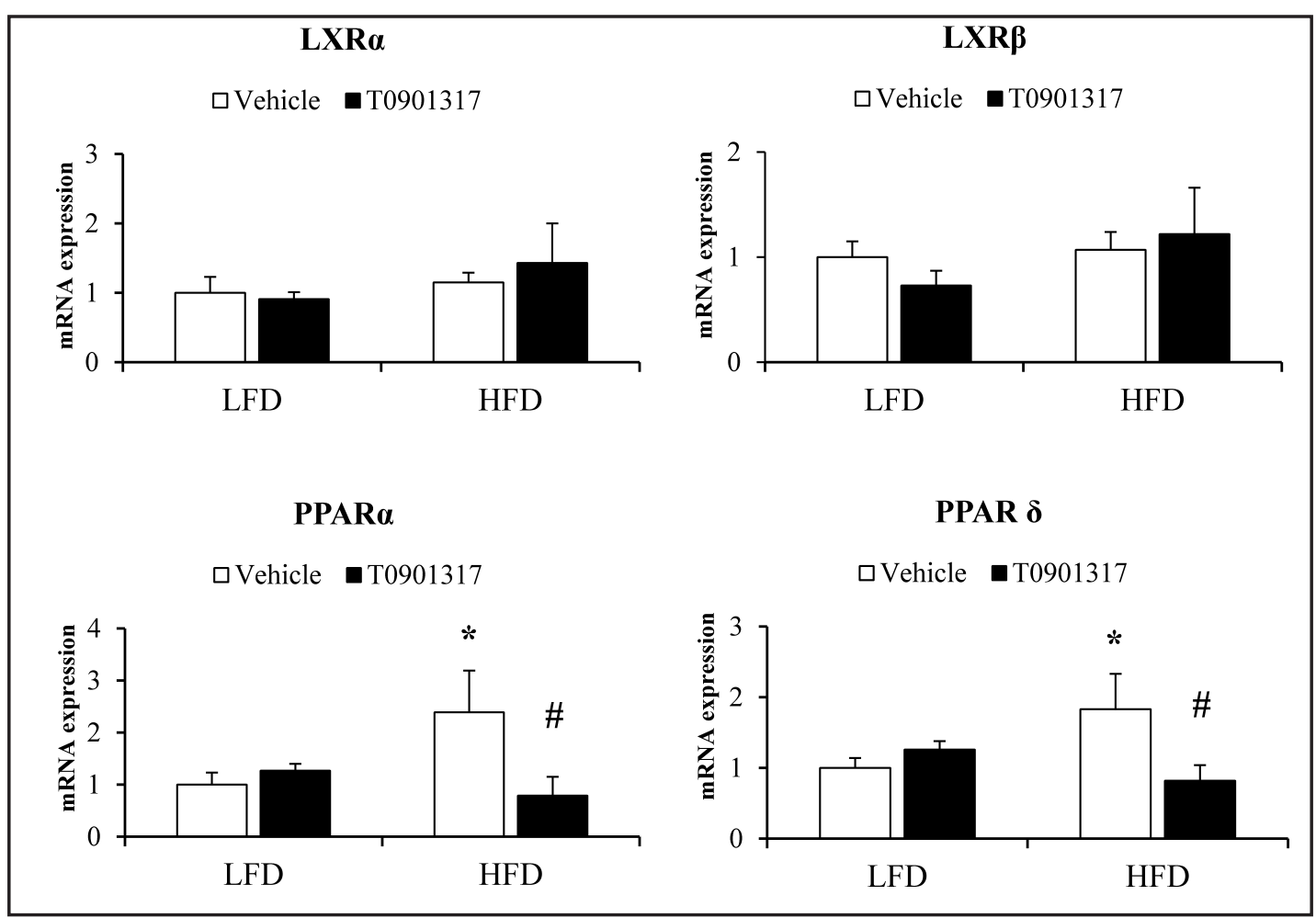

Fig. 2. Effect of T0901317 treatment on mRNA expression of selected genes in the heart. Fold change vs. low fat diet (LFD) vehicle group. The results are means \pm SD $(n=6) . *$ - significant difference versus LFD vehicle group . \# - significant difference versus high fat diet (HFD) vehicle group. LXR $\alpha$ - liver X receptor $\alpha$. LXR $\beta$ - liver X receptor $\beta$. PPAR $\alpha$ - peroxisome proliferator-activated receptor $\alpha$. PPAR $\delta$ - peroxisome proliferatoractivated receptor $\delta$.

Table 2. Average Ct values of measured genes determined after realtime PCR. The results are means \pm SD $(n=6)$. Ct - threshold cycle. $\mathrm{LXR} \alpha-$ liver X receptor $\alpha$. LXR $\beta$ - liver X receptor $\beta$. PPAR $\alpha$ - peroxisome proliferator-activated receptor $\alpha$. PPAR $\delta$ - peroxisome proliferator-activated receptor $\delta$

\begin{tabular}{lcccc}
\hline & \multicolumn{2}{c}{ LFD } & \multicolumn{2}{c}{ HFD } \\
& Vehicle & T0901317 & Vehicle & T0901317 \\
\hline LXR $\alpha$ & $24.60 \pm 0.37$ & $25.98 \pm 0.52$ & $25.11 \pm 0.47$ & $23.24 \pm 0.67$ \\
LXR $\beta$ & $21.87 \pm 0.35$ & $23.43 \pm 0.76$ & $22.50 \pm 0.47$ & $20.75 \pm 0.84$ \\
PPAR $\alpha$ & $20.45 \pm 0.38$ & $21.23 \pm 0.59$ & $19.92 \pm 0.61$ & $19.87 \pm 0.75$ \\
PPAR $\delta$ & $20.33 \pm 0.38$ & $21.15 \pm 0.69$ & $20.20 \pm 0.23$ & $19.49 \pm 0.51$ \\
\hline
\end{tabular}

(Fig. 2). Table 2 lists average cycle threshold (Ct) values of measured genes determined after real-time PCR.

Protein content of LXR $\alpha$, LXR $\beta$ and FAT/CD36 in cardiac muscle of rat fed on low fat diet remained stable after treatment with T0901317 (Fig. 3). The agonist also had no impact on the level of these proteins in animals fed on high fat diet (Fig. 3). On the other hand, content of myocardial mature form of SREBP-1 decreased after LXR activation in both diet groups. (Fig. 3).

\section{Disscusion}

In the present study we found that both isoforms of LXR are expressed in the rat heart and that LXR $\beta$ is more abundant than LXR $\alpha$. Our data obtained previously indicate also that 


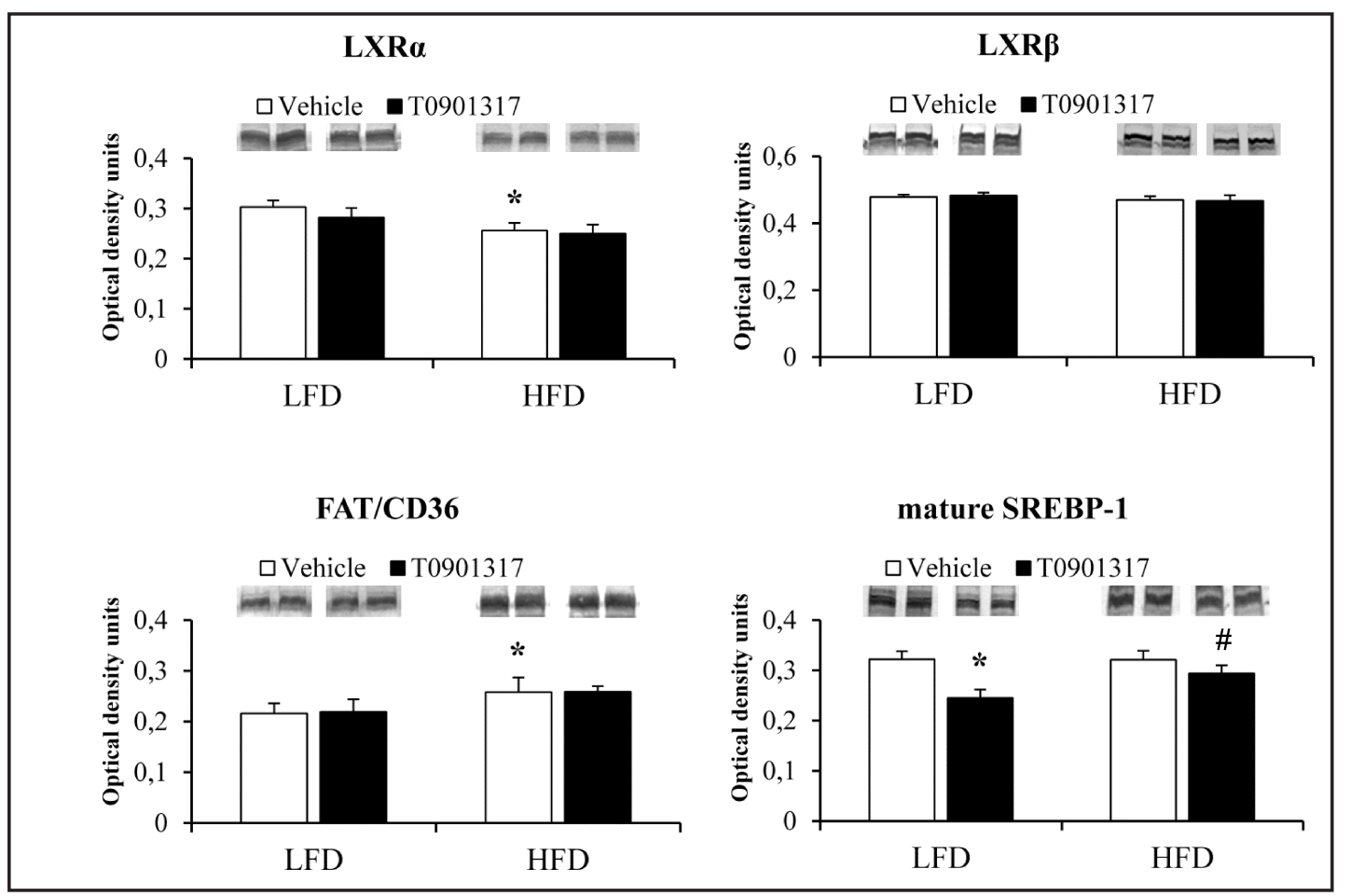

Fig. 3. Effect of T0901317 treatment on protein expression of selected genes in the heart. The results are means \pm SD $(n=4)$. * - significant difference versus low fat diet (LFD) vehicle group. \# - significant difference versus high fat diet (HFD) vehicle group. LXR $\alpha$ - liver X receptor $\alpha$. LXR $\beta$ - liver X receptor $\beta$. FAT/CD36 fatty acid translocase/CD36. SREBP-1- sterol response element binding protein 1.

in rat skeletal muscles LXR $\beta$ expression is higher than LXR $\alpha$ [27]. Others reported that LXR $\beta$ is the dominant isoform in the heart and skeletal muscle of mice $[2,8,28]$ and in human skeletal muscle $[29,30]$.

We did not observe changes in myocardial LXRs expression after administration of T0901317 either at mRNA or protein level. Similar observation for murine heart was reported by Lei et al. [8] where mRNA expression of both LXR isoforms was unchanged after GW3965 injections. Treatment with T0901317 did not affect the expression levels of LXR $\alpha$ and LXR $\beta$ also in the mouse myotubes [28, 31]. It has been shown that LXR $\alpha$ expression is controlled by an autoregulatory mechanism and synthetic as well as natural LXR agonists increased LXR $\alpha$ expression in human macrophages, adipocytes, hepatocytes, skin fibroblasts and myotubes [30, 32-36]. Ulven et al. [37] observed that T0901317 increased the amount of LXR $\alpha$ mRNA in mouse white adipose tissue but not in other examined cells. Lack of changes of LXR expression after administration of T0901317 in our study does not mean lack of activation of LXRs which were present in cardiomyocytes. Previous publications of other authors indicated activity of LXRs as transcription factors in the myocardium. Steffensen et al. [9] analysed LXR agonist-induced changes by genome-wide expression-profiling analysis of seven organs, including heart, from mice treated orally with T0901317. LXR agonist treatment altered expression profiles of genes involved in lipid, cholesterol and carbohydrate metabolism not only in liver, but also in adrenal, kidney, lung and heart [9]. Kuipers et al. [10] showed that like in other tissues, mRNA expression of specific target genes of LXR is increased in the heart of mice treated with T0901317, which means that LXR specific pathways are activated by T0901317 treatment in the myocardium.

We observed an increase in plasma triacylglycerols and NEFA concentration after T0901317 administration. This is well-known effect of LXRs activation that causes hyperlipidemia in rodents by stimulation of expression of hepatic lipogenic genes. As a result, the level of triacylglycerols, phospholipids and free fatty acids rises in plasma $[16,38,39]$. 
We did not observed changes in plasma cholesterol level and myocardial cholesterol content in animals fed on either LFD or HFD diet after treatment with T0901317. The content of myocardial cholesterol esters after T0901317 administration decreased in animals fed on LFD and did not change in animals fed on HFD. Reboulleau et al. [40] observed that treatment with a cocktail of LXR/RXR agonists (22-hydroxy-cholesterol/9-cis-retinoic acid) induced cholesterol efflux from neonatal rat cardiomyocytes and this is one of the mechanisms by which cells maintain their cholesterol pools. We may speculate that similar mechanism was activated in our in vivo settings. Cholesterol is a key component of cell membranes and maintenance of a constant cholesterol level in cardiomyocytes is required for proper functioning of the membrane-bound enzymes and cation transporters [41].

It can be expected that high plasma lipid concentration would lead to increased flux of free fatty acids into the myocardium, contributing to intracellular lipid accumulation. However we did not observe lipid accumulation in the rat heart after treatment with T0901317. Out of all examined lipid fractions only triacylglycerols content was moderately increased in the heart of animals fed on LFD after LXR activation. Sugden and Holness [42] reported cardiac triacylglycerol accumulation in mouse fed for 5 days with standard diet supplemented with T0901317. Similarly, Lei et al. [8] found increased level of triacylglycerols in mouse cardiac tissue after in vivo GW3965 injections. Furthermore GW3965 influenced triacylgliceryde composition in favor of monounsaturates [8]. We also observed that T0901317 affected cardiac fatty acids profile of triacylglycerols in the rat heart, and this was reflected by increased content of monounsaturated fatty acids (data not shown). According to some researchers $[30,43,44]$ accumulation of triacylglycerols in non-adipose tissues is not harmful, it is rather accumulation of intermediary metabolites, such as long-chain acylCoAs, ceramides and diacylglycerols that may have toxic effects on cells. Probably these intermediary metabolites did not accumulate in the cells during triglyceride synthesis [30, 45]. This is consistent with our observations, as triacylglycerols content was elevated, while ceramide content decreased after T0901317 treatment.

In animals fed on HFD a significant increase in plasma triacylglycerols and NEFA concentrations occurred after T0901317 administration. Despite increased availability of lipids in plasma we did not find myocardial lipid accumulation. LXR agonist slightly raised only phospholipid content. There was a decrease in NEFA and ceramide level and no change in concentration of other examined lipid fractions in the rat heart.

Why LXR-induced hyperlipidemia does not lead to myocardial lipid accumulation in rats? Firstly, LXR $\beta$ is the dominant isoform in the rat heart and perhaps activation primarily of this isoform caused observed changes. There is a tissue-specific expression of both isoforms of LXRs, so probably there are tissue-selective functions for them [2]. Moreover even the same isoform could create distinct changes because of the presence of specific intracellular coactivators, corepressors and endogenous ligands within different cells [9, 46-48].

Secondly, there were no changes in expression of myocardial FAT/CD36 protein after LXR activation in high fat diet fed animals. In heart as well as in skeletal muscle increase of the expression of FAT/CD36 is followed by the increase of fatty acid uptake [49].

Another possible explanation of the absence of lipid accumulation in the heart was increase of the rate of myocardial lipids utilization after LXR activation. I our study we did not observe increase of expression of peroxisome proliferator-activated receptor $\alpha$ gene (PPAR $\alpha$ ) in the rat heart after administration of T0901317, however elevation of the efficiency of $\beta$-oxidation cannot be excluded. Wright et al. [50] reported increase of myocardial fatty acid utilization in mice after 5 weeks of HFD, although there were no change in mRNA level of PPAR $\alpha$. PPAR $\alpha$ is a transcription factor and increased utilization of fatty acids might result in an increase in PPAR $\alpha$ activity and not necessarily PPAR $\alpha$ expression itself [51]. Sugden and Holness [42] demonstrated that T0901317 activation in vivo causes a marked enhancement of protein expression of cardiac pyruvate dehydrogenase kinase 4 (PDK4), enzyme which promotes fatty acid oxidation and is one of PPAR $\alpha$ target genes [50]. Expression of PDK4 gene is not covered by this study, but we cannot rule out possibility that T0901317 have an impact on content and activity of myocardial enzymes involved in cardiac lipid metabolism.

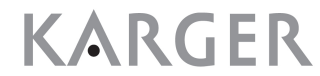


Absence of lipid accumulation in the rat heart might be explained by inhibition of lipogenesis in cardiac cells. In the heart of animals treated with LXR agonist there was a decrease in the mature form of SREBP-1 protein level. SREBP-1c is a transcription factor that controls lipogenesis and is activated during overnutrition [52]. Marfella et al. [52] observed an increase in cardiac level o SREBP-1c and intramyocyte lipid accumulation in the heart of patients with metabolic syndrome [52]. According to Marfella et al. [52] these results imply that SREBP-1c could play a role in the regulation of intracellular lipid stores in the human heart, as it has been observed in the liver cells [53].

Cells of non-adipose tissues have a limited capacity for storage of lipids. When this capacity is exceeded, content of lipids may be reduced by its export from cells to plasma in the form of lipoproteins [22]. It appears that the heart, like liver or intestine, is a lipoproteinsecreting organ and is able to produce and secrete apolipoproteins B (apoB) [54-56]. ApoB secretion prevented cardiac triacylglycerols accumulation in fat-fed transgenic mice with overexpression of human apoB in the heart $[57,58]$. In mice T0901317 stimulate, both in vivo and in vitro, the expression of apolipoprotein $\mathrm{E}$ in skeletal muscles [28], apolipoprotein $\mathrm{D}$ in adipocytes [59], apolipoprotein A-IV in hepatocytes [60]. In hamsters T0901317 led to increased plasma triglyceride apoB, due to enhanced hepatic secretion of apoB-containing lipoproteins [61]. It might be that LXR activation in rats causes increase of expression or secretion of apolipoproteins from the heart as a protection from lipid accumulation.

In summary we have found that LXR $\beta$ is the dominant isoform in the heart of rats. Administration of T0901317 caused increase of triacylglycerols and NEFA concentration in plasma, which is consistent with previous reports of other authors, and this applies to both diet group. LXR agonist elevated content of myocardial triacylglycerols in animals fed on LFD and content of phospholipids in animals fed on HFD, whereas the level of the remaining examined lipid classes was decreased or not affected after LXR activation. In conclusion administration of T0901317 induces hyperlipidemia but does not lead to severe lipid accumulation in the rat heart.

\section{Acknowledgements}

This work was supported by the Medical University of Bialystok (grants no. 124-18525L and 134-18712L).

\section{Disclosure Statement}

None declared

\section{References}

1 Committee NRN: A unified nomenclature system for the nuclear receptor superfamily. Cell 1999;97:161163.

2 Zhang Y, Mangelsdorf DJ: Luxuries of lipid homeostasis: The unity of nuclear hormone receptors, transcription regulation, and cholesterol sensing. Mol Interv 2002;2:78-87.

3 Bełtowski J: Liver x receptors (lxr) as therapeutic targets in dyslipidemia. Cardiovasc Ther 2008;26:297316.

4 Janowski BA, Grogan MJ, Jones SA, Wisely GB, Kliewer SA, Corey EJ, Mangelsdorf DJ: Structural requirements of ligands for the oxysterol liver x receptors lxralpha and lxrbeta. Proc Natl Acad Sci U S A 1999;96:266-271.

-5 Wu S, Yin R, Ernest R, Li Y, Zhelyabovska O, Luo J, Yang Y, Yang Q: Liver x receptors are negative regulators of cardiac hypertrophy via suppressing nf-kappab signalling. Cardiovasc Res 2009;84:119-126. 
6 Chen M, Beaven S, Tontonoz P: Identification and characterization of two alternatively spliced transcript variants of human liver x receptor alpha. J Lipid Res 2005;46:2570-2579.

7 Cheng Y, Liu G, Pan Q, Guo S, Yang X: Elevated expression of liver x receptor alpha (lxr $\alpha$ ) in myocardium of streptozotocin-induced diabetic rats. Inflammation 2011;34:698-706.

-8 Lei P, Baysa A, Nebb HI, Valen G, Skomedal T, Osnes JB, Yang Z, Haugen F: Activation of liver x receptors in the heart leads to accumulation of intracellular lipids and attenuation of ischemia-reperfusion injury. Basic Res Cardiol 2013;108:323.

-9 Steffensen KR, Neo SY, Stulnig TM, Vega VB, Rahman SS, Schuster GU, Gustafsson JA, Liu ET: Genome-wide expression profiling; a panel of mouse tissues discloses novel biological functions of liver $\mathrm{x}$ receptors in adrenals. J Mol Endocrinol 2004;33:609-622.

10 Kuipers I, Li J, Vreeswijk-Baudoin I, Koster J, van der Harst P, Silljé HH, Kuipers F, van Veldhuisen DJ, van Gilst WH, de Boer RA: Activation of liver x receptors with t0901317 attenuates cardiac hypertrophy in vivo. Eur J Heart Fail 2010;12:1042-1050.

11 Zhao C, Dahlman-Wright K: Liver x receptor in cholesterol metabolism. J Endocrinol 2010;204:233-240.

12 Peet DJ, Turley SD, Ma W, Janowski BA, Lobaccaro JM, Hammer RE, Mangelsdorf DJ: Cholesterol and bile acid metabolism are impaired in mice lacking the nuclear oxysterol receptor lxr alpha. Cell 1998;93:693704.

13 Nomiyama T, Bruemmer D: Liver x receptors as therapeutic targets in metabolism and atherosclerosis. Curr Atheroscler Rep 2008;10:88-95.

-14 Repa JJ, Turley SD, Lobaccaro JA, Medina J, Li L, Lustig K, Shan B, Heyman RA, Dietschy JM, Mangelsdorf DJ: Regulation of absorption and abc1-mediated efflux of cholesterol by rxr heterodimers. Science 2000;289:1524-1529.

15 Zhou J, Febbraio M, Wada T, Zhai Y, Kuruba R, He J, Lee JH, Khadem S, Ren S, Li S, Silverstein RL, Xie W: Hepatic fatty acid transporter cd36 is a common target of lxr, pxr, and ppargamma in promoting steatosis. Gastroenterology 2008;134:556-567.

16 Schultz JR, Tu H, Luk A, Repa JJ, Medina JC, Li L, Schwendner S, Wang S, Thoolen M, Mangelsdorf DJ, Lustig KD, Shan B: Role of lxrs in control of lipogenesis. Genes Dev 2000;14:2831-2838.

17 Liang G, Yang J, Horton JD, Hammer RE, Goldstein JL, Brown MS: Diminished hepatic response to fasting/ refeeding and liver $\mathrm{x}$ receptor agonists in mice with selective deficiency of sterol regulatory elementbinding protein-1c. J Biol Chem 2002;277:9520-9528.

18 Cao G, Liang Y, Broderick CL, Oldham BA, Beyer TP, Schmidt RJ, Zhang Y, Stayrook KR, Suen C, Otto KA, Miller AR, Dai J, Foxworthy P, Gao H, Ryan TP, Jiang XC, Burris TP, Eacho PI, Etgen GJ: Antidiabetic action of a liver $\mathrm{x}$ receptor agonist mediated by inhibition of hepatic gluconeogenesis. J Biol Chem 2003;278:11311136.

19 Laffitte BA, Chao LC, Li J, Walczak R, Hummasti S, Joseph SB, Castrillo A, Wilpitz DC, Mangelsdorf DJ, Collins JL, Saez E, Tontonoz P: Activation of liver x receptor improves glucose tolerance through coordinate regulation of glucose metabolism in liver and adipose tissue. Proc Natl Acad Sci U S A 2003;100:54195424.

20 Taegtmeyer H: Tracing cardiac metabolism in vivo: One substrate at a time. J Nucl Med 2010;51 Suppl 1:80S-87S.

-21 Lopaschuk GD, Stanley WC: Malonyl-coa decarboxylase inhibition as a novel approach to treat ischemic heart disease. Cardiovasc Drugs Ther 2006;20:433-439.

-22 Schaffer JE: Lipotoxicity: When tissues overeat. Curr Opin Lipidol 2003;14:281-287.

23 Roemen TH, van der Vusse GJ: Application of silica gel column chromatography in the assessment of nonesterified fatty acids and phosphoglycerides in myocardial tissue. J Chromatogr 1985;344:304-308.

24 Nawrocki A, Górski J: Effect of plasma free fatty acid concentration on the content and composition of the free fatty acid fraction in rat skeletal muscles. Horm Metab Res 2004;36:601-606.

25 Baranowski M, Zabielski P, Blachnio A, Gorski J: Effect of exercise duration on ceramide metabolism in the rat heart. Acta Physiol (Oxf) 2008;192:519-529.

26 Pfaffl MW: A new mathematical model for relative quantification in real-time rt-pcr. Nucleic Acids Res 2001;29:e45.

27 Baranowski M, Blachnio-Zabielska AU, Zabielski P, Harasim E, Harasiuk D, Chabowski A, Gorski J: Liver x receptor agonist t0901317 enhanced peroxisome proliferator-activated receptor-delta expression and fatty acid oxidation in rat skeletal muscle. J Physiol Pharmacol 2013;64:289-297. 
28 Hessvik NP, Boekschoten MV, Baltzersen MA, Kersten S, Xu X, Andersén H, Rustan AC, Thoresen GH: Lxr\{beta\} is the dominant lxr subtype in skeletal muscle regulating lipogenesis and cholesterol efflux. Am J Physiol Endocrinol Metab 2010;298:E602-613.

29 Abdallah BM, Beck-Nielsen H, Gaster M: Increased expression of 11beta-hydroxysteroid dehydrogenase type 1 in type 2 diabetic myotubes. Eur J Clin Invest 2005;35:627-634.

30 Cozzone D, Debard C, Dif N, Ricard N, Disse E, Vouillarmet J, Rabasa-Lhoret R, Laville M, Pruneau D, Rieusset J, Lefai E, Vidal H: Activation of liver x receptors promotes lipid accumulation but does not alter insulin action in human skeletal muscle cells. Diabetologia 2006;49:990-999.

-31 Muscat GE, Wagner BL, Hou J, Tangirala RK, Bischoff ED, Rohde P, Petrowski M, Li J, Shao G, Macondray G, Schulman IG: Regulation of cholesterol homeostasis and lipid metabolism in skeletal muscle by liver $\mathrm{x}$ receptors. J Biol Chem 2002;277:40722-40728.

32 Hessvik NP, Bakke SS, Smith R, Ravna AW, Sylte I, Rustan AC, Thoresen GH, Kase ET: The liver x receptor modulator 22(s)-hydroxycholesterol exerts cell-type specific effects on lipid and glucose metabolism. J Steroid Biochem Mol Biol 2012;128:154-164.

-33 Kase ET, Andersen B, Nebb HI, Rustan AC, Thoresen GH: 22-hydroxycholesterols regulate lipid metabolism differently than t0901317 in human myotubes. Biochim Biophys Acta 2006;1761:1515-1522.

34 Laffitte BA, Joseph SB, Walczak R, Pei L, Wilpitz DC, Collins JL, Tontonoz P: Autoregulation of the human liver x receptor alpha promoter. Mol Cell Biol 2001;21:7558-7568.

-35 Li Y, Bolten C, Bhat BG, Woodring-Dietz J, Li S, Prayaga SK, Xia C, Lala DS: Induction of human liver x receptor alpha gene expression via an autoregulatory loop mechanism. Mol Endocrinol 2002;16:506-514.

-36 Whitney KD, Watson MA, Goodwin B, Galardi CM, Maglich JM, Wilson JG, Willson TM, Collins JL, Kliewer SA: Liver $\mathrm{x}$ receptor (lxr) regulation of the lxralpha gene in human macrophages. J Biol Chem 2001;276:4350943515.

-37 Ulven SM, Dalen KT, Gustafsson JA, Nebb HI: Tissue-specific autoregulation of the lxralpha gene facilitates induction of apoe in mouse adipose tissue. J Lipid Res 2004;45:2052-2062.

-38 Grefhorst A, Elzinga BM, Voshol PJ, Plösch T, Kok T, Bloks VW, van der Sluijs FH, Havekes LM, Romijn JA, Verkade HJ, Kuipers F: Stimulation of lipogenesis by pharmacological activation of the liver x receptor leads to production of large, triglyceride-rich very low density lipoprotein particles. J Biol Chem 2002;277:34182-34190.

39 Repa JJ, Liang G, Ou J, Bashmakov Y, Lobaccaro JM, Shimomura I, Shan B, Brown MS, Goldstein JL, Mangelsdorf DJ: Regulation of mouse sterol regulatory element-binding protein-1c gene (srebp-1c) by oxysterol receptors, lxralpha and lxrbeta. Genes Dev 2000;14:2819-2830.

40 Reboulleau A, Robert V, Vedie B, Doublet A, Grynberg A, Paul JL, Fournier N: Involvement of cholesterol efflux pathway in the control of cardiomyocytes cholesterol homeostasis. J Mol Cell Cardiol 2012;53:196205.

41 Saini HK, Arneja AS, Dhalla NS: Role of cholesterol in cardiovascular dysfunction. Can J Cardiol 2004;20:333-346.

42 Sugden MC, Holness MJ: Mechanisms underlying regulation of the expression and activities of the mammalian pyruvate dehydrogenase kinases. Arch Physiol Biochem 2006;112:139-149.

-43 Listenberger LL, Han X, Lewis SE, Cases S, Farese RV, Ory DS, Schaffer JE: Triglyceride accumulation protects against fatty acid-induced lipotoxicity. Proc Natl Acad Sci U S A 2003;100:3077-3082.

-44 Liu L, Yu S, Khan RS, Ables GP, Bharadwaj KG, Hu Y, Huggins LA, Eriksson JW, Buckett LK, Turnbull AV, Ginsberg HN, Blaner WS, Huang LS, Goldberg IJ: Dgat1 deficiency decreases ppar expression and does not lead to lipotoxicity in cardiac and skeletal muscle. J Lipid Res 2011;52:732-744.

45 Liu L, Zhang Y, Chen N, Shi X, Tsang B, Yu YH: Upregulation of myocellular dgat1 augments triglyceride synthesis in skeletal muscle and protects against fat-induced insulin resistance. J Clin Invest 2007;117:1679-1689.

46 Hu X, Li S, Wu J, Xia C, Lala DS: Liver x receptors interact with corepressors to regulate gene expression. Mol Endocrinol 2003;17:1019-1026.

47 Miao B, Zondlo S, Gibbs S, Cromley D, Hosagrahara VP, Kirchgessner TG, Billheimer J, Mukherjee R: Raising hdl cholesterol without inducing hepatic steatosis and hypertriglyceridemia by a selective lxr modulator. J Lipid Res 2004;45:1410-1417. 
48 Mouzat K, Prod'homme M, Volle DH, Sion B, Déchelotte P, Gauthier K, Vanacker JM, Lobaccaro JM: Oxysterol nuclear receptor lxrbeta regulates cholesterol homeostasis and contractile function in mouse uterus. J Biol Chem 2007;282:4693-4701.

49 Glatz JF, Luiken JJ, Bonen A: Membrane fatty acid transporters as regulators of lipid metabolism: Implications for metabolic disease. Physiol Rev 2010;90:367-417.

50 Wright JJ, Kim J, Buchanan J, Boudina S, Sena S, Bakirtzi K, Ilkun O, Theobald HA, Cooksey RC, Kandror KV, Abel ED: Mechanisms for increased myocardial fatty acid utilization following short-term high-fat feeding. Cardiovasc Res 2009;82:351-360.

51 Sharma S, Adrogue JV, Golfman L, Uray I, Lemm J, Youker K, Noon GP, Frazier OH, Taegtmeyer H: Intramyocardial lipid accumulation in the failing human heart resembles the lipotoxic rat heart. FASEB J 2004;18:1692-1700.

52 Marfella R, Di Filippo C, Portoghese M, Barbieri M, Ferraraccio F, Siniscalchi M, Cacciapuoti F, Rossi F, D'Amico M, Paolisso G: Myocardial lipid accumulation in patients with pressure-overloaded heart and metabolic syndrome. J Lipid Res 2009;50:2314-2323.

53 Horton JD, Shimomura I, Ikemoto S, Bashmakov Y, Hammer RE: Overexpression of sterol regulatory element-binding protein-1a in mouse adipose tissue produces adipocyte hypertrophy, increased fatty acid secretion, and fatty liver. J Biol Chem 2003;278:36652-36660.

54 Borén J, Véniant MM, Young SG: Apo b100-containing lipoproteins are secreted by the heart. J Clin Invest 1998;101:1197-1202.

-55 Nielsen LB, Sullivan M, Vanni-Reyes T, Goldberg IJ, Young SG: The dna sequences required for apolipoprotein b expression in the heart are distinct from those required for expression in the intestine. J Mol Cell Cardiol 1999;31:695-703.

56 Nielsen LB, Véniant M, Borén J, Raabe M, Wong JS, Tam C, Flynn L, Vanni-Reyes T, Gunn MD, Goldberg IJ, Hamilton RL, Young SG: Genes for apolipoprotein b and microsomal triglyceride transfer protein are expressed in the heart: Evidence that the heart has the capacity to synthesize and secrete lipoproteins. Circulation 1998;98:13-16.

57 Bartels ED, Nielsen JM, Hellgren LI, Ploug T, Nielsen LB: Cardiac expression of microsomal triglyceride transfer protein is increased in obesity and serves to attenuate cardiac triglyceride accumulation. PLoS One 2009;4:e5300.

58 Yokoyama M, Yagyu H, Hu Y, Seo T, Hirata K, Homma S, Goldberg IJ: Apolipoprotein b production reduces lipotoxic cardiomyopathy: Studies in heart-specific lipoprotein lipase transgenic mouse. J Biol Chem 2004;279:4204-4211.

59 Hummasti S, Laffitte BA, Watson MA, Galardi C, Chao LC, Ramamurthy L, Moore JT, Tontonoz P: Liver x receptors are regulators of adipocyte gene expression but not differentiation: Identification of apod as a direct target. J Lipid Res 2004;45:616-625.

-60 Wójcicka G, Jamroz-Wiśniewska A, Horoszewicz K, Bełtowski J: Liver x receptors (lxrs). Part i: Structure, function, regulation of activity, and role in lipid metabolism. Postepy Hig Med Dosw (Online) 2007;61:736759.

61 Basciano H, Miller A, Baker C, Naples M, Adeli K: Lxralpha activation perturbs hepatic insulin signaling and stimulates production of apolipoprotein b-containing lipoproteins. Am J Physiol Gastrointest Liver Physiol 2009;297:G323-332. 